\title{
Biodiversity Observations
}

http://bo.adu.org.za

\section{An electronic journal published by the Animal Demography Unit at the University of Cape Town}

The scope of Biodiversity Observations consists of papers describing observations about biodiversity in general, including animals, plants, algae and fungi. This includes observations of behaviour, breeding and flowering patterns, distributions and range extensions, foraging, food, movement, measurements, habitat and colouration/plumage variations. Biotic interactions such as pollination, fruit dispersal, herbivory and predation fall within the scope, as well as the use of indigenous and exotic species by humans. Observations of naturalised plants and animals will also be considered. Biodiversity Observations will also publish a variety of other interesting or relevant biodiversity material: reports of projects and conferences, annotated checklists for a site or region, specialist bibliographies, book reviews and any other appropriate material. Further details and guidelines to authors are on this website.

Paper Editor: Alexandre Roulin

\section{WEAVERS AS PREY OF BARN OWLS}

\section{H. Dieter Oschadleus}

Recommended citation format:

Oschadleus HD 2018. Weavers as prey of Barn Owls. Biodiversity Observations, Vol 9.1:1-8

URL: https://journals.uct.ac.za/index.php/BOJ/article/view/400

Published online: 29 January 2018 


\section{PREDATION}

\section{WEAVERS AS PREY OF BARN OWLS}

\section{H. Dieter Oschadleus}

Animal Demography Unit, Department of Biological Sciences, University of Cape Town, Rondebosch, 7701 South Africa; doschadleus@gmail.com

\section{Abstract}

Barn Owls Tyto alba are widespread globally, and feed largely on rodents, but also birds. In Africa, weavers are an important component of avian prey. 46 papers were found that list weavers as prey of Barn Owls, with 11 species of Ploceidae weavers identified to species level, although there are likely many other weaver species that have been taken but not yet identified. Hunting strategies of the Barn Owl are taking weavers at their nests at night (four records), or taking roosting weavers from reedbeds. Barn Owls have been recorded at Red-billed Quelea Quelea quelea colonies, where they presumably pick up recently fledged juveniles.

\section{Introduction}

Barn Owls Tyto alba are widespread globally, and they feed largely on rodents, but also other small mammals, birds, reptiles, amphibians and insects (Bruce et al. 2017). In Africa, birds feature widely in the diet of Barn Owls, especially in urban areas (Hockey et al. 2005), and weavers are a large component of avian prey (Taylor 1994). Many weaver species roost in reeds or trees in large numbers, and many species are colonial when breeding (del Hoyo et al. 2010), and thus are vulnerable to predation by these owls.

\section{Methods}

References to weavers as prey of Barn Owls were searched widely, both in peer reviewed journals and local bird club newsletters, using an unpublished bibliography of the Ploceidae family. For identified weaver species, mean mass was taken from Fry \& Keith (2004) for African weavers, and from Safford \& Hawkins (2013) for Madagascan weavers.

\section{Results}

Individuals of eleven weaver species have been taken as prey by the Barn Owl (Table 1). No records of Barn Owls preying on Asian weavers were found. Most records were based on prey remains in pellets regurgitated by the owls. In Village Weavers Ploceus cucullatus, nests were attacked by this owl (see Discussion). Most studies that recorded weavers as prey of Barn Owls were from South Africa, but there were studies from East Africa, West Africa, and Madagascar. Mass of weaver species taken averaged from $12 \mathrm{~g}$ (Scaly-feathered Finch Sporopipes squamifrons) to $45 \mathrm{~g}$ (Cape Weaver Ploceus capensis).

\section{Discussion}

Most studies involve the usual analysis of Barn Owl pellets (24 studies). Usually weavers, as with other prey items, are identified by skulls (and feathers). In some cases, metal bird rings provide unique identification of individual birds (Hewitt 1962, Oatley 1990, Oschadleus 2000, Rowan 1964, Anon. 1955). Another 22 papers were anecdotal observations of predation or listing predation records as part of other studies.

\section{Weaver species recorded as prey}

Eleven weaver species were recorded as prey items of the Barn Owl, with the Red-billed Quelea the most often recorded species. The quelea is considered the most numerous bird globally (Bruggers \& Elliott 1989), so this is not surprising. The next most frequently 
recorded species were Southern Red Bishop Euplectes orix and Southern Masked Weaver Ploceus velatus, both very common species in southern Africa. These three weaver species are colonial and regularly roost in reeds (Fry \& Keith 2004), thus are likely targets as prey for Barn Owls residing near the weaver colonies or roost sites. The Spectacled Weaver Ploceus ocularis is monogamous, but small numbers may join mixed species weaver roosts (e.g. at Darvill, Pietermaritzburg, South Africa). The other weaver species listed are gregarious (Scaly-feathered Finch) or colonial (Fry \& Keith 2004), including the Madagascar Fody Foudia madagascariensis (Safford \& Hawkins 2013). The White-browed Sparrow-weaver Plocepasser mahali and Scaly-feathered Finch are found in savanna, including drier areas than for the other weavers (Fry \& Keith 2004). Mass of weavers taken as prey varies from 12 to $45 \mathrm{~g}$, well within the weight range of small rodents taken, i.e. 7-110g (Hockey et al. 2005).

Probably many other weaver species are taken as prey, but have not been identified to species level, e.g. Safford \& Hawkins (2013) noted that Comoro Fodies Foudia eminentissima may be prey items for Barn Owls. A large number of studies recorded weavers to family or genus level. No records of Barn Owls preying on Asian weavers were found, but the search of Asian literature was less comprehensive than that for African weavers.

\section{Hunting methods by Barn Owls}

Weavers are diurnal, and thus it may seem strange that they are an important component of avian prey taken by the nocturnally hunting Barn Owl. However, many weavers are common, widespread in Africa and the Indian Ocean islands, and often found in large numbers. Thus individual Barn Owls may adapt to hunting sleeping weavers, either in the roosts or nests of the weavers.
In urban areas in kwaZulu-Natal, South Africa, Barn Owls have been observed taking weavers, including Village Weavers, at their nests at night (Adams 2009, Caine 2007, Hoffman 2009, Young 2009). Young (2009) described the technique as follows. The owl hangs upsidedown on a nest by its talons, holding its wings open for balance, puts its head into a nest to extract the prey, which is taken to a nearby branch and ripped apart. This strategy has been likened to the technique of the diurnal African Harrier Hawk (Caine 2007). This behaviour was also used by Barn Owls taking swifts from their nests (Ewbank 1984). In addition to the above records, Chapin (1939) observed a Barn Owl with a weaver, which may have been taken from a nest - interestingly, this occurred during daylight - diurnal hunting is known for this owl (Bruce et al. 2017).

Some weavers roost in their nests during the non-breeding season (Oschadleus et al. 2017), rather than in large roosts in reeds or tree twigs, though this may represent low numbers in general. In the breeding season males, females and chicks would be present in nests, providing a greater chance of a Barn Owl finding food in weaver colonies. This hunting technique may be more common than suggested by these four anecdotal records, at least in local areas where the owls have learned to use nearby weaver colonies as a food source. It would be worthwhile placing camera traps at likely colonies to record nocturnal predation events.

Many authors refer to Barn Owls preying on roosting flocks of weavers (e.g. Taylor 1994), but few details are available. Grant (2013) noted Barn and Spotted Eagle Owls Bubo africanus catching quelea roosting in reeds at night, with the quelea constantly being disturbed by the owls. Presumably the owls grab quelea that perchroost on reeds, while the owl is in flight.

Red-billed Quelea breeding colonies attract a large variety of predators (Bruggers \& Elliott 1989), especially birds of prey, and

- ISSN 2219-0341 - 
including Barn Owls. The hunting strategy by Barn Owls at these colonies (Jarvis \& Vernon 1989, Lourens 1963, Thiollay 1978, Thiollay 1989, Vernon 1970) is not described but may be different to the strategies described for other weaver colonies. Other raptors prey on inexperienced fledglings soon after leaving the nest, by moving around the colony to take the easy pickings, and owls may use similar techniques.

\section{References}

Adams B. 2009. Link. Animals. Witness 18 December:16

Anonymous. 1955. Ringing recoveries. Witwatersrand Bird Club News Sheet 18:4-5.

Bruce, MD, Christie, DA, Kirwan, GM \& Marks, JS. 2017. Common Barn-owl (Tyto alba). In: del Hoyo, J, Elliott, A, Sargatal, J, Christie, DA \& de Juana, E (eds.). Handbook of the Birds of the World Alive. Lynx Edicions, Barcelona. (retrieved from https://www.hbw.com/node/54929 on 7 November 2017).

Bruggers RL, Elliott CCH (eds). 1989. Quelea quelea: Africa's bird pest. Oxford University Press, Oxford.

Caine T 2007. Barn Owl robbing weaver nests. Gabar 18(1):34.

Chapin JP 1939. The birds of the Belgian Congo. Part 2. Bulletin of the American Museum of Natural History 75: 1-632.

del Hoyo J, Elliott A, Christie DA (eds). 2010. Handbook of the Birds of the World. Vol 15. Lynx Edicions, Barcelona.

Ewbank DA. 1984. Barn Owl behaviour. Honeyguide 30:124.

Fry CH, Keith S (eds). 2004. Birds of Africa. Vol 7. Christopher Helm, London
Grant K. 2013. Notes from Kevin Grant in Ghanzi. Familiar Chat March: 3

Hewitt J. 1962. Feeding habit. Witwatersrand Bird Club News Sheet 42: $1-5$

Hockey PAR, Dean WRJ, and Ryan PG (eds). 2005. Roberts' Birds of Southern Africa (7th edn). Black Eagle Publishing, Cape Town

Hoffman S. 2009. Predatory owls. Witness 22 December:11

Jarvis MJF \& Vernon CJ. 1989. Notes on quelea breeding in southern Africa. In: Mundy 1989a pp. 50-68

Lourens DC. 1963. The Red-billed Quelea. A contribution to the bioecology and control. Unpubl. DSc, Faculty of Agriculture, University of Pretoria.

Oatley T. 1990. Tales of old rings. Birding in Southern Africa 42: 98100

Oschadleus D. 2000. Safring News. Owl pellets. Africa - Birds \& Birding 5(4):16.

Oschadleus HD, Schultz B, Schultz S. 2017. Cape Sparrows roosting in Cape Weaver nests in Cape Town. Biodiversity Observations 8.11: $1-7$

Rowan MK. 1964. An analysis of the records of a South African ringing station. Ostrich 35:160-187.

Safford R, Hawkins F. 2013. The Birds of Africa, Volume 8: The Malagasy Region. Christopher Helm, London. 
Taylor I. 1994 Barn Owls. Predator-prey relationships and conservation. Cambridge University Press, Cambridge

Thiollay J-M. 1978. Production et taux de mortalité dans les colonies de Quelea quelea (Aves: Ploceidae) en Afrique Centrale. [Production and rate of mortality in the colonies of Quelea quelea (Aves: Ploceidae) in Central Africa.] Tropical Ecology 19:7-24.

Thiollay J-M. 1989. Natural predation on quelea. In: Bruggers RL, Elliott CCH (eds). 1989. Quelea quelea: Africa's bird pest. Oxford University Press, Oxford. pp216-229 (ch 16).

Vernon CJ. 1970. Report on Quelea quelea colony - Sinamatela, Wankie National Park - 13 February-8 March, 1970. Unpublished (report). 19 pp.

Young A. 2009. Owl on the prowl. KZN Birds 26:26. 
Table 1. Published records of Barn Owls predating weaver birds. First author and year are given (references for Table follow), country or region of study abbreviated as: ao Angola, bw Botswana, cd DRCongo, do Dominican Republic, ke Kenya, mg Madagascar, mw Malawi, na Namibia, ng Nigeria, sn Senegal, za South Africa, zw Zimbabwe, Wafr West Africa

\begin{tabular}{|c|c|c|c|c|}
\hline Weaver species & Studies & Other records & Mass & $\begin{array}{l}\text { No. of } \\
\text { papers }\end{array}$ \\
\hline $\begin{array}{l}\text { White-browed Sparrow-weaver } \\
\text { Plocepasser mahali }\end{array}$ & za: Vernon 1972 & & 42.2 & 1 \\
\hline $\begin{array}{l}\text { Scaly-feathered Finch Sporopipes } \\
\text { squamifrons }\end{array}$ & $\begin{array}{l}\text { na: Dean } 1975 \\
\text { za: Dean } 1975, \text { Nel } 1965\end{array}$ & & 11.7 & 2 \\
\hline Red-billed Quelea Quelea quelea & $\begin{array}{l}\text { za: Dean } 1977 \\
\text { zw: Vernon 1980a }\end{array}$ & $\begin{array}{l}\text { bw: Grant } 2013 \\
\text { za: Leask 2002, Lourens 1963, Tucker } 1957 \\
\text { zw: Brooke 1972, Jarvis 1989, Vernon } 1970 \\
\text { WAfr: Thiollay 1978, Thiollay } 1989\end{array}$ & 19.1 & 11 \\
\hline $\begin{array}{l}\text { Yellow-crowned Bishop Euplectes } \\
\text { afer }\end{array}$ & sn: Yalden 1994 & & 14.1 & 1 \\
\hline $\begin{array}{l}\text { Southern Red Bishop Euplectes } \\
\text { orix }\end{array}$ & $\begin{array}{l}\text { za: Dean 1977, Herholdt 1986, Kopij 1997, } \\
\text { Vernon 1980b }\end{array}$ & $\begin{array}{l}\text { za: Anon. 1955, Hewitt 1962, Oatley 1990, } \\
\text { Oschadleus 2000, Rowan } 1964\end{array}$ & 20.0 & 9 \\
\hline $\begin{array}{l}\text { Madagascar Fody Foudia } \\
\text { madagascariensis }\end{array}$ & $\begin{array}{l}\text { mg: Goodman 1993, Goodman 2009, Goodman } \\
\text { 2014, Rasoma } 2007\end{array}$ & & 16.7 & 4 \\
\hline Cape Weaver Ploceus capensis & za: Grindley 1973, Wirminghaus 1989 & za: Rowan 1964 & 44.9 & 3 \\
\hline $\begin{array}{l}\text { Southern Masked Weaver Ploceus } \\
\text { velatus }\end{array}$ & $\begin{array}{l}\text { na: Dean } 1975 \\
\text { za: Dean } 1977, \text { Grindley 1973, Herholdt 1986, } \\
\text { Kopij } 1997\end{array}$ & za: Oschadleus 2000, Rowan 1964 & 28.7 & 7 \\
\hline Village Weaver Ploceus cucullatus & za: Bateman 1960, Caine 2007 & $\begin{array}{l}\text { cd: Chapin } 1939 \\
\text { do: Wiley } 2001 \\
\text { za: Thring } 1942\end{array}$ & 36.2 & 5 \\
\hline $\begin{array}{l}\text { Sakalava Weaver Ploceus } \\
\text { sakalava }\end{array}$ & $\begin{array}{l}\text { mg: Goodman 1993, Goodman 2009, Goodman } \\
\text { 2014, Rasoma } 2007\end{array}$ & & 23.7 & 4 \\
\hline $\begin{array}{l}\text { Spectacled Weaver Ploceus } \\
\text { ocularis }\end{array}$ & za: Bateman 1960 & & 25.7 & 1 \\
\hline & & & & \\
\hline
\end{tabular}




\begin{tabular}{|c|c|c|c|c|}
\hline Weavers & $\begin{array}{l}\text { ao: Dean } 1974 \\
\text { ke: Gichuki } 1987 \\
\text { mw: Hanney } 1963 \\
\text { ng: Lekunze } 2001 \\
\text { na+za: Vernon } 1972 \\
\text { za: Grindley 1973, Kilpin 2000, Kopij 1997, Kopij } \\
\text { et al. 2014, Skead 1956, Vernon 1972, Vernon } \\
\text { 1983 } \\
\text { zw: Vernon } 1980 \text { a }\end{array}$ & $\begin{array}{l}\text { za: Adams 2009, Hoffman 2009, Kolbe 1946, } \\
\text { Rowan 1964, Young } 2009\end{array}$ & $n / a$ & 18 \\
\hline
\end{tabular}

\section{References for Table 1.}

Adams B 2009 Link. Animals. Witness 18 Dec:16

Anonymous. 1955 Ringing recoveries. Witwatersrand Bird Club News Sheet 18:4-5

Bateman JA 1960 Owl habits from pellets. Zoological Society of Southern Africa News Bulletin 1(3):20-21

Brooke RK, Grobler JH, Irwin MPS, Steyn P 1972 A study of the migratory eagles Aquila nipalensis and A. pomarina (Aves: Accipitridae) in southern Africa, with comparative notes on other large raptors. Occasional Papers of the National Museums Rhodesia B. 5:61-114

Caine T 2007 Barn Owl robbing weaver nests. Gabar 18(1):34

Chapin JP 1939 The birds of the Belgian Congo. Part 2. Bulletin of the American Museum of Natural History 75:1-632

Dean WRJ 1974 Analysis of Tyto alba pellets from Angola. Zoologica africana 9:89-92

Dean WRJ 1975 Tyto alba prey in South West Africa and the Northern Cape. Zoologica africana 10(2):217-219

Dean WRJ 1977 The ecology of owls at Barberspan, Transvaal. Proceedings of the Symposium on African Predatory Birds. Northern Transvaal Ornithological Society, Pretoria 1:25-45

Gichuki CM 1987 Diet of the Barn Owl, Tyto alba (Scopoli), in Nairobi, Kenya. Journal of the East Africa Natural History Society and National Museum 187: 1-7

Goodman SM, Langrand O, Raxworthy CJ 1993 The food habits of the Barn Owl Tyto alba at three sites on Madagascar. Ostrich 64:160-171

Goodman SM, Griffiths O 2009 Notes on the diet of the Barn Owl (Aves: Tytonidae: Tyto alba) from Zohin'Andavaka, Beahitse, extreme southwestern Madagascar. Malagasy Nature 2:163-166

Goodman SM, Mittermeier JC, Ramamonjisoa J, Rene de Roland L-A 2014 The dietary habits of Barn Owls Tyto alba) in the spiny bush of southwestern Madagascar. Malagasy Nature 8: 67-72

Grant K 2013 Notes from Kevin Grant in Ghanzi. Familiar Chat Mar: 3

Grindley J, Siegfried WR, Vernon CJ 1973 Diet of the Barn Owl in the Cape Province. Ostrich 44:266-267

Hanney P 1963 Observations upon the food of the Barn Owl (Tyto alba) in Southern Nyasaland, with a method of ascertaining population dynamics of rodent prey. Annals and magazine of natural history 6(65):305-313 
Herholdt JJ 1986 Diet of the Barn Owl at a riverine roost in the central Orange Free State. Ostrich 57:185-187

Hewitt J 1962 Feeding habit. Witwatersrand Bird Club News Sheet 42: 1-5

Hoffman S 2009 Predatory owls. Witness 22 Dec:11

Jarvis MJF, Vernon CJ 1989 Notes on quelea breeding in southern Africa. In: Mundy 1989a pp. 50-68

Kilpin A 2000 Preliminary owl survey at Phinda. CCA (Conservation Corporation Africa?) Ecological Journal 2:205-208

Kolbe FF 1946 The case for the Barn Owl. African Wildlife 1(1): 69-73

Kopij G 1997 Food of the Barn Owl Tyto alba in a farmland near Bloemfontein, South Africa. Journal of African Raptor Biology 12(1\&2):20-23

Kopij G, Symes CT, Bruyns R 2014 Dietary Overlap of Co-Occurring Barn Owl Tyto alba Scopoli and Spotted Eagle Owl Bubo africanus Temminck in Urban and Rural Environments. Polish Journal of Ecology 62: 801-805

Leask T 2002 Owl oddities. KZN Birds 1:15-16

Lekunze LM, Ezealor AU, Aken'Ova T 2001 Prey groups in the pellets of the barn owl Tyto alba (Scopoli) in the Nigerian savanna. African Journal of Ecology 39:38-44

Lourens DC 1963 The Red-billed Quelea. A contribution to the bio-ecology and control. Unpubl. DSc, Faculty of Agriculture, University of Pretoria. $400 \mathrm{pp}$

Nel JAJ, Nolte H 1965 Notes on the prey of owls in the Kalahari Gemsbok National Park, with special reference to the small mammals. Koedoe 8:75-81

Oatley T 1990 Tales of old rings. Birding in Southern Africa 42: 98-100

Oschadleus [H]D 2000 Safring News. Owl pellets. Africa - Birds \& Birding 5(4):16

Rasoma J, Goodman SM 2007 Food habits of the Barn Owl (Tyto alba) in spiny bush habitat of arid southwestern Madagascar. Journal of Arid Environments 69:537-543

Rowan MK 1964 An analysis of the records of a South African ringing station. Ostrich 35:160-187

Skead CJ 1956 Prey of the Barn Owl. Ostrich 27:148

Thiollay J-M 1978 Production et taux de mortalité dans les colonies de Quelea quelea (Aves: Ploceidae) en Afrique Centrale. [Production and rate of mortality in the colonies of Quelea quelea (Aves: Ploceidae) in Central Africa.] Tropical Ecology 19:7-24

Thiollay J-M 1989 Natural predation on quelea. In: Bruggers 1989a 216-229 (ch 16)

Thring D 1942 Correspondence. Ostrich 13:177

Tucker B 1957 Barn Owl diet. Witwatersrand Bird Club News Sheet 23:6

Vernon CJ 1970 Report on Quelea quelea colony - Sinamatela, Wankie National Park - 13 February-8 March, 1970. Unpublished (report). 19 pp

Vernon CJ 1972 An analysis of owl pellets collected in southern Africa. Ostrich 43:109-123

Vernon CJ 1980a Prey of the Barn Owl from the Lundi River. Honeyguide 101:10-13

Vernon CJ 1980b Prey of a Barn Owl at Port Alfred. Diaz Diary 87: 8

Vernon C 1983 Notes from the border - 11. [Prey of the Barn Owl around East London] The Bee-eater Suppl. 10: 8-9

Wiley JW 2001 Green heron (Butorides virescens) predation at Village Weaver (Ploceus cucullatus) nests. El Pitirre, Society of Caribbean Ornithology 14(3):130-133

Wirminghaus JO 1989 The diet of barn owls at a roost near Grahamstown. South African Journal of Zoology 24:232-234

Yalden DW 1994 A note on the diet of Barn Owls Tyto alba at Djoudj, Senegal. Malimbus 16: 53-55 
Young A 2009 Owl on the prowl. KZN Birds 26:26

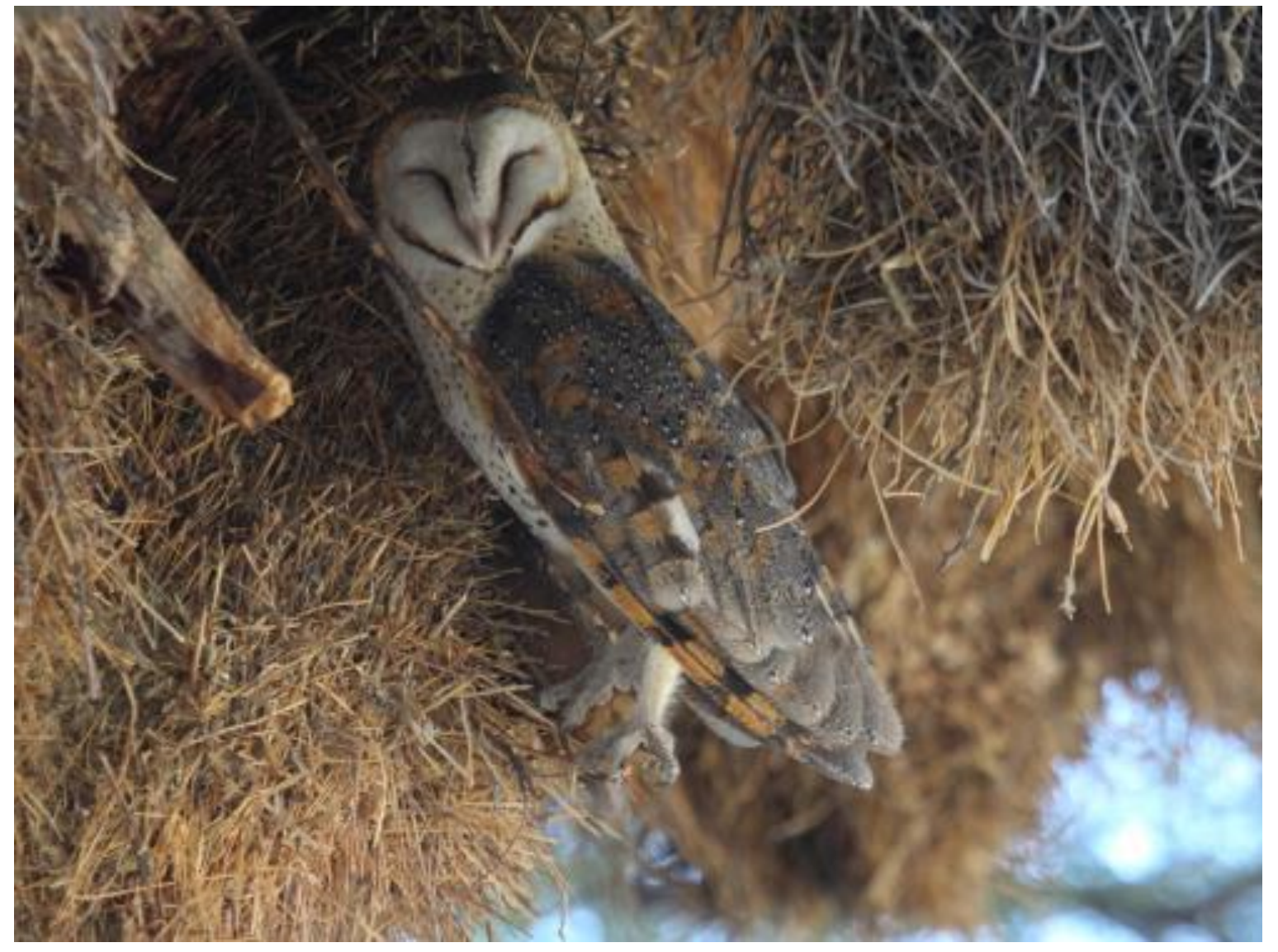

Figure 1. Barn Owls sometimes roost or breed in Sociable Weaver nests, but have not yet been recorded as preying on Sociable Weavers (Photo: Phillip Nieuwoudt, from http://vmus.adu.org.za/?vm=BirdPix-21574) 